\title{
Measures of excess body weight and anthropometry among adult Albertans: cross-sectional results from Alberta's tomorrow project cohort
}

Darren R. Brenner ${ }^{1,2^{*}}$ D, Abbey E. Poirier ${ }^{1}$, Tiffany R. Haig ${ }^{3}$, Alianu Akawung ${ }^{3}$, Christine M. Friedenreich ${ }^{1,2}$ and Paula J. Robson ${ }^{3,4}$

\begin{abstract}
Background: Excess body weight during adulthood has been consistently associated with all-cause mortality, cardiovascular disease, and cancer at multiple sites among other chronic diseases. We describe the prevalence of excess body weight and abdominal obesity reported by participants enrolled in Alberta's Tomorrow Project (ATP).

Methods: ATP is a geographically-based cohort study conducted among adults aged 35-69 years from across the province of Alberta. Participants completed anthropometric measures and health and lifestyle questionnaires at enrolment. Overweight and obese were categorized as a body mass index (BMI) of $25.0-29.9 \mathrm{~kg} / \mathrm{m}^{2}$ and $\geq 30 \mathrm{~kg} / \mathrm{m}^{2}$, respectively. Abdominal obesity was categorized using cut-offs of waist circumference of $>94 \mathrm{~cm}$ for men and $>80 \mathrm{~cm}$ for women and waist-tp-hip ratio cut-offs of $>0.90$ for men and $>0.85$ for women.

Results: BMI and hip and waist circumference data were obtained from 12,062 men and 18,853 women enrolled between 2001 and 2009. Overall, $76.8 \%$ of men and 59.5\% of women reported $\mathrm{a} B M \mathrm{Bl} \geq 25 \mathrm{~kg} / \mathrm{m}^{2}$. The proportions of overweight and obese were significantly higher in older age groups $(p<0.001)$. In addition, the proportion of participants reporting being overweight and obese was higher among lower education $(p<0.001)$ and lower income groups $(p<0.001)$. Overall, approximately two thirds of men and women in ATP cohort reported abdominal obesity. Overweight, obesity and abdominal obesity were all associated with a history of several cardiometabolic chronic conditions including hypertension, heart attack, angina, high cholesterol, stroke and diabetes.
\end{abstract}

Conclusion: A large majority of ATP participants were overweight and carried excess abdominal fat. Strategies to improve energy balance among Albertans are encouraged and may have a notable impact on future chronic disease burden.

Keywords: Overweight, Obesity, Cohort, Abdominal adiposity, Chronic disease

\footnotetext{
* Correspondence: Darren.Brenner@ahs.ca

'Department of Cancer Epidemiology and Prevention Research,

CancerControl Alberta, Alberta Health Services Holy Cross Centre, Room 514,

Box ACB, 2210 2nd Street SW, Calgary, AB T2S 3C3, Canada

${ }^{2}$ Department of Oncology and Department of Community Health Sciences,

Cumming School of Medicine, University of Calgary, Calgary, Canada

Full list of author information is available at the end of the article
} 


\section{Background}

Excess body weight has been consistently related to a broad array of adverse health outcomes including diabetes, cardiovascular disease and multiple cancer sites, among other chronic diseases and all-cause mortality [1, 2]. The increased caloric density in Western diets, increases in sedentary behaviours/sedentary time and decreases in recreational and transport-related physical activity have all led to a shift in caloric balance at the population level [3]. Sustained imbalance has led to rising obesity rates and specifically, abdominal obesity. Globally, the prevalence of overweight rose from $24.6 \%$ in 1980 to $34.4 \%$ in 2008 while the prevalence of obesity rose from $6.4 \%$ to $12.0 \%$. [4] National surveys conducted by the Public Health Agency of Canada have shown that the prevalence of obesity (body mass index [BMI] $>30 \mathrm{~kg} / \mathrm{m} 2$ ) is on the rise. Based on a 2011 report, the overall proportion of Canadian adults affected by obesity ( $>18$ years of age) almost doubled between 1978 (13.8\%) and 2008 (25.4\%) [5].

Two separate analyses using comparable methods estimated that obesity costs the Canadian economy between five and seven billion dollars annually through direct healthcare costs and indirect costs $[5,6]$. Therefore, the rising rates of obesity in the population are cause for immediate concern from both public health and economic perspectives.

In this study, we examined the predictors of overweight, obesity and abdominal obesity in the adult Albertan population, which have not yet been well characterized. To quantify the population-level burden of obesity among adult Alberta's Tomorrow Project (ATP) participants, we estimated the prevalence of overweight/obesity using BMI and waist-to-hip ratio as well as abdominal obesity using waist circumference as reported by participants enrolled in ATP. We also examined the relation between body size and the prevalence of chronic disease in the ATP population.

\section{Methods}

ATP is a geographically-based prospective cohort comprised of 54,942 Albertans between the ages of 35-69 years established to examine the association between various lifestyle factors and chronic disease outcomes. The present analyses were conducted on a subset of the cohort, which included only the 30,915 participants recruited during the first phase of recruitment (2001-2009) who completed the anthropometric section of the Health and Lifestyle Questionnaire (HLQ) at enrolment. Detailed information on the feasibility of recruitment methods, enrollment and data collection for ATP has been previously published [7, 8].

Participants were asked to use a scale to measure weight (in pounds) and were supplied with a tape measure (divided in $1 / 8^{\prime \prime}$ sections) and detailed instructions, supported by diagrams, to record height (in feet and inches), and waist and hip circumferences (in inches). In addition, Participants were asked to record their anthropometric measurements in a single session at least two hours after a meal, preferably with the assistance of another adult, and to record each measure twice. Participants who were more than 12 weeks pregnant, or less than six months postpartum, were not included in these analyses. Missing, contradictory, ambiguous or out of range anthropometric measures were identified by two data reviewers, and participants were contacted by phone for clarification.

BMI was calculated using participants' self-reported height and weight measurements $\left(\mathrm{kg} / \mathrm{m}^{2}\right)$. BMI categories were classified as normal weight $(\mathrm{BMI}<25)$, overweight (BMI $\geq 25,<30)$ and obese (BMI $\geq 30)$. Waist and hip circumferences measured in inches were converted to centimetres. Participants were categorized according to World Health Organization (WHO) waist circumference guidelines that recommend using cut-offs of $>94 \mathrm{~cm}$ for men and $>80 \mathrm{~cm}$ for women to categorize Western populations into those with abdominal obesity [9]. Additionally, the WHO has provided another set of waist circumference cut-offs that have been found to be associated with substantially higher risk of cardiometabolic complications $(>102 \mathrm{~cm}$ for men and $>88 \mathrm{~cm}$ for women). Waist-to-hip ratio was also calculated, and participants were classified according to WHO guidelines that suggest individuals with a waist-to-hip ratio $>0.90$ for men and $>0.85$ for women are at an increased risk for metabolic complications [9].

\section{Statistical analysis}

Descriptive statistics were used to characterize the cohort according to anthropometric measures. Means and standard deviations (SD) summarized continuous variables and frequencies and percentages were used to capture categorical variables. Variable distributions were examined and any outlying or aberrant values were verified using the original questionnaires. Pearson's chi-square tests were conducted to compare demographic variables and chronic disease outcomes between groups of participants categorized by $\mathrm{BMI}$, waist circumference and waist-to-hip ratio. Logistic regression models for BMI, waist circumference and waist-to-hip ratio were run separately for men and women and were adjusted for age, educational attainment, marital status, annual household income, employment status, smoking status and geographic location (urban/ rural). For each anthropometric outcome, linear regression was used to determine if correlations between sociodemographic variables were significantly impacting the associations between the individual sociodemographic variables and BMI and waist circumference. All statistical tests were performed at a $5 \%$ level of significance using SAS version 9.2 (SAS Institute, Cary, NC). 
Table 1 Body mass index ${ }^{a}$ of Alberta's Tomorrow Project participants by socio-demographic categories ${ }^{b}$

\begin{tabular}{|c|c|c|c|c|c|c|c|c|c|c|}
\hline \multirow[b]{2}{*}{ Variables } & \multirow[b]{2}{*}{$\mathrm{n}$} & \multicolumn{4}{|c|}{ Men $(n=12,062)(\%)$} & \multicolumn{5}{|c|}{ Women $(n=18,853)(\%)$} \\
\hline & & $\begin{array}{l}\text { Underweight } \\
(0.2)\end{array}$ & $\begin{array}{l}\text { Normal } \\
(23.0)\end{array}$ & $\begin{array}{l}\text { Overweight } \\
(48.4)\end{array}$ & $\begin{array}{l}\text { Obese } \\
(28.4)\end{array}$ & $\mathrm{n}$ & $\begin{array}{l}\text { Underweight } \\
(1.1)\end{array}$ & $\begin{array}{l}\text { Normal } \\
(39.4)\end{array}$ & $\begin{array}{l}\text { Overweight } \\
(33.2)\end{array}$ & $\begin{array}{l}\text { Obese } \\
(26.4)\end{array}$ \\
\hline \multicolumn{11}{|l|}{ Age } \\
\hline $35-44$ & 3860 & 0.2 & 27.1 & 48.0 & 24.7 & 6173 & 1.5 & 48.0 & 29.2 & 21.3 \\
\hline $45-54$ & 4283 & 0.1 & 22.5 & 48.6 & 28.8 & 6623 & 1.0 & 39.3 & 33.3 & 26.5 \\
\hline $55-64$ & 2924 & 0.1 & 20.0 & 48.2 & 31.7 & 4479 & 0.7 & 31.4 & 36.6 & 31.3 \\
\hline$\geq 65$ & 995 & 0.2 & 18.6 & 50.2 & 31.1 & 1578 & 1.1 & 29.2 & 38.2 & 31.5 \\
\hline missing & 0 & & & & & 0 & & & & \\
\hline \multicolumn{11}{|l|}{ Education } \\
\hline High school not completed & 1323 & 0.2 & 18.5 & 47.2 & 34.2 & 1694 & 1.1 & 28.5 & 34.5 & 35.9 \\
\hline High school completed & 1793 & 0.3 & 18.5 & 49.2 & 32.1 & 3916 & 1.1 & 35.1 & 33.8 & 30.0 \\
\hline Some post-secondary ${ }^{c}$ & 2248 & 0.1 & 20.6 & 46.9 & 32.4 & 4197 & 1.2 & 36.4 & 34.2 & 28.2 \\
\hline Post-secondary completed & 6696 & 0.2 & 25.9 & 49.0 & 24.9 & 9042 & 1.0 & 44.7 & 32.2 & 22.1 \\
\hline missing & 2 & & & & & 4 & & & & \\
\hline \multicolumn{11}{|l|}{ Marital Status } \\
\hline Married/Living with partner & 9959 & 0.1 & 21.8 & 49.5 & 28.6 & 14,251 & 1.0 & 40.3 & 33.6 & 25.1 \\
\hline Single (never married) & 792 & 0.6 & 34.2 & 37.8 & 27.4 & 1025 & 1.6 & 35.1 & 28.1 & 35.2 \\
\hline Divorced/separated/widowed & 1308 & 0.1 & 25.8 & 46.6 & 27.5 & 3571 & 1.3 & 37.2 & 32.9 & 28.7 \\
\hline missing & 3 & & & & & 6 & & & & \\
\hline \multicolumn{11}{|l|}{ Household Income $^{d}$} \\
\hline$<\$ 30,000$ & 1107 & 0.5 & 26.8 & 43.4 & 29.3 & 2972 & 1.6 & 31.8 & 31.2 & 35.4 \\
\hline$\$ 30,000-\$ 49,000$ & 2976 & 0.2 & 24.9 & 45.9 & 29.0 & 5347 & 1.0 & 35.1 & 34.9 & 29.0 \\
\hline$\$ 50,000-\$ 79,000$ & 3333 & 0.1 & 23.2 & 48.7 & 28.0 & 4463 & 0.9 & 39.8 & 32.9 & 26.4 \\
\hline$\geq \$ 80,000$ & 4457 & 0.1 & 20.7 & 51.1 & 28.1 & 5507 & 1.0 & 47.8 & 32.1 & 19.1 \\
\hline missing & 189 & & & & & 564 & & & & \\
\hline \multicolumn{11}{|l|}{ Occupational Status } \\
\hline Full Time & 9178 & 0.1 & 23.5 & 49.0 & 27.4 & 8452 & 1.0 & 39.9 & 32.7 & 26.4 \\
\hline Part Time/Homemaker & 777 & 0.1 & 25.2 & 50.5 & 24.2 & 6767 & 1.2 & 43.1 & 32.3 & 23.4 \\
\hline Unemployed/Student & 302 & 0.0 & 25.8 & 42.1 & 32.1 & 490 & 2.0 & 38.8 & 32.5 & 26.7 \\
\hline Retired & 1419 & 0.2 & 18.3 & 47.8 & 33.8 & 2471 & 0.8 & 30.7 & 37.6 & 31.0 \\
\hline Other & 383 & 0.5 & 21.9 & 39.2 & 38.4 & 664 & 1.4 & 28.0 & 31.6 & 39.0 \\
\hline missing & 3 & & & & & 9 & & & & \\
\hline \multicolumn{11}{|l|}{ Geographic Location ${ }^{\mathrm{e}}$} \\
\hline Rural & 2755 & 0.1 & 20.1 & 48.1 & 31.7 & 4563 & 0.9 & 34.0 & 33.8 & 31.3 \\
\hline Urban & 9307 & 0.2 & 23.9 & 48.5 & 27.4 & 14,290 & 1.1 & 41.2 & 33.0 & 24.8 \\
\hline missing & 0 & & & & & 0 & & & & \\
\hline \multicolumn{11}{|l|}{ Smoking Status } \\
\hline Current daily smoker & 1918 & 0.4 & 31.0 & 45.7 & 22.9 & 2862 & 2.9 & 40.1 & 33.4 & 23.6 \\
\hline Current occasional smoker & 420 & 0.0 & 21.4 & 49.5 & 29.1 & 544 & 1.7 & 41.2 & 35.9 & 21.3 \\
\hline Former smoker & 4730 & 0.1 & 17.0 & 49.5 & 33.4 & 6773 & 0.6 & 35.1 & 33.9 & 30.4 \\
\hline Never smoker & 4985 & 0.2 & 25.8 & 48.4 & 25.6 & 8655 & 0.8 & 42.5 & 32.3 & 24.4 \\
\hline missing & 9 & & & & & 19 & & & & \\
\hline
\end{tabular}

Note: all the variables tested were highly significantly different, assessed by Pearson chi-square test $(p<0.001)$

${ }^{\mathrm{a} B M I}$ derived from participant self-reported height and weight. BMI is missing for 157 participants (54 men and 103 women)

${ }^{\mathrm{b}}$ Alberta's Tomorrow Project data at enrolment

'Some post-secondary includes combined responses to: some technical school/college, completed technical school/ college, part of university degree completed

dincome data are in response to a question about total household income before tax.

${ }^{e} G$ Geographic location determined using postal codes, with rural areas identified according to rural postal code classification (second digit $=0$ ) 


\section{Results}

\section{Body mass index}

Table 1 presents the BMI categories by socio-demographic variables. Of the participants enrolled between 2001 and 2009, information on BMI was available from 12,062 men and 18,853 women. Overall, $48.4 \%(n=5843)$ of men and $33.2 \%(n=6251)$ of women were classified as overweight while $28.4 \%(n=3424)$ of men and $26.4 \%(n=4967)$ of women were considered obese. Obesity was more prevalent in those who had completed lower levels of education and those were retired, unemployed or students. The prevalence of obesity was lower in higher household income categories $(p<0.001)$. In both men and women, highest rates of obesity were observed in former smokers compared to other smoking statuses.

In order to compare measures of BMI to other population-based surveys in Canada, we examined the agreement with the Canadian Community Health Survey (CCHS) data collected in 2005 (Cycle 3.1), available through Statistics Canada [10]. Although we restricted the CCHS data to Albertan respondents aged 35-69 years to coincide with the ATP inclusion criteria, the CCHS data did include significantly more participants between the ages of 65-69 (Additional file 1: Table S1). In the ATP cohort, $76.8 \%$ of men and $59.6 \%$ of women were classified as overweight or obese compared to $65.4 \%$ of men and $48.1 \%$ of women in the CCHS subsample (Additional file 1: Table S1).

The results of the multinomial logistic regression for overweight, obesity and sociodemographic variables are presented in Table 2 . In women, compared to those with a household income $\geq \$ 80,000$, those with a household income of $<\$ 30,000$ had a higher odds of being overweight (OR: 1.25, 95\% CI: 1.10-1.42) or obese (OR: 2.15, 95\% CI: 1.88-2.46). However, in men, having a household income $<\$ 80,000$ was associated with a decreased odds of being overweight or obese. Living in a rural area compared to living in an urban area was associated with a greater odds of obesity in men (OR: 1.34, 95\% CI: 1.18-1.52) and women (OR: 1.37, 95\% Ci: 1.25-1.49). Compared to never smokers, male (OR: 1.71, 95\% CI: 1.51-1.93) and female (OR: 1.41, 95\% CI: 1.30-1.53) former smokers were more likely to be obese.

In both men and women, the prevalence of overweight and obesity in the ATP cohort was significantly higher in those with a history of hypertension, heart attack, angina, high cholesterol, stroke, diabetes and polyps in the colon (Table 3 ). In addition, $48.4 \%$ of men with Crohn's disease were overweight.

\section{Waist circumference}

Table 4 presents sex-specific waist circumference cut-off categories by demographic variables. Information on waist circumference was available for 12,042 men and 18,787 women. Among participants, $67.4 \%$ of men reported waist circumference $>94 \mathrm{~cm}$ and $67.0 \%$ of women $>80 \mathrm{~cm}$. The prevalence of participants with a waist circumference that exceeded the healthy cut-off was higher among older age groups. Conversely, the prevalence of participants meeting healthy waist circumference cut-offs was greater among individuals with higher household income and education attainment (Table 4). Among cohort participants, more women $(44.3 \%)$ than men $(40.7 \%)$ were observed in the extremely high risk waist circumference category. In current occasional smokers, $72.9 \%$ of participants had a waist circumference in the elevated risk category. For all other smoking statuses, the percent of participants in the elevated risk category ranged from $63.4 \%$ to $66.6 \%$.

Table 5 presents the results of the logistic regression model for waist circumference and sociodemographic variables. Compared to men who work full-time, men who are retired have a higher odds of having a waist circumference $>94 \mathrm{~cm}$ (OR: 1.29, 95\% CI: 1.08-1.53) and $>102$ (OR: 1.27, 95\% CI: 1.09-1.47). The odds of having a waist circumference in the elevated risk category was greater for both rural men and women (OR: 1.19, 95\% CI: 1.08-1.32) and women (OR: 1.19, 95\% CI: 1.101.29). Compared to never smokers, former smokers were more likely to have a waist circumference in the elevated risk category in men (OR: 1.48, 95\% CI: 1.35-1.62) and women (OR: 1.35, 95\% CI: 1.26-1.45).

Significant positive associations were observed between both the elevated risk and extremely high risk waist circumference categories and a history of hypertension, angina, high cholesterol, stroke, diabetes and polyps in the colon (Table 6). In addition to these associations, those in the extremely high risk waist circumference category were also more likely to have a history of Crohn's disease (Table 6).

\section{Waist-to-hip ratio}

Sex-specific waist-to-hip ratio cut-off categories by demographic variables are also presented in Table 4. Information on waist-to-hip ratio was available for 11,919 men and 18,730 women in ATP cohort. Overall, $85.4 \%$ of men and $38.9 \%$ of women had waist-to-hip ratios that exceeded healthy cut-offs of $\geq 0.90$ and $\geq 0.85$, respectively. The prevalence of participants exceeding the cut-offs for waistto-hip ratio was higher among older age groups, and was lower in groups that reported higher educational attainment and greater household income.

Based on the logistic regression model (Table 5), living in a rural area compared to an urban area was associated with a higher odds of having a waist-to-hip ratio above the cut-off in men (OR: 1.24, 95\% CI: 1.09-1.41). In women, having a household income $<\$ 30,000$ was associated with a higher odds of having a waist-to-hip ratio above the cutoff (OR: 1.68, 95\% CI: 1.51-1.88). Compared to never 
Table 2 Odds of higher body mass index by baseline sociodemographic characteristics in Alberta's Tomorrow Project Cohort from Multinomial Logistic Regression"

\begin{tabular}{|c|c|c|c|c|c|c|}
\hline \multirow[t]{2}{*}{ Sociodemographic factors } & \multicolumn{3}{|c|}{ Men $(n=11,857) \dagger$} & \multicolumn{3}{|c|}{ Women $(n=18,259) \neq$} \\
\hline & $\begin{array}{l}\leq 24.9: \\
\text { Normal }\end{array}$ & $\begin{array}{l}\text { 25.0-29.9: } \\
\text { Overweight }^{\mathrm{a}}\end{array}$ & $\begin{array}{l}\geq 30: \\
\text { Obese }^{\text {a }}\end{array}$ & $\begin{array}{l}\leq 24.9 \text { : } \\
\text { Normal }\end{array}$ & $\begin{array}{l}\text { 25.0-29.9: } \\
\text { Overweight }^{\mathrm{a}}\end{array}$ & $\begin{array}{l}\text { ב30: } \\
\text { Obese }^{\text {a }}\end{array}$ \\
\hline \multirow[t]{2}{*}{$n(\%)$} & $2750(23.19)$ & 3365 (28.38) & $5742(48.43)$ & $7417(40.62)$ & $4823(26.41)$ & $6019(32.96)$ \\
\hline & & OR $[95 \% \mathrm{Cl}]$ & OR [95\% Cl] & & OR $[95 \% \mathrm{Cl}]$ & OR $[95 \% \mathrm{Cl}]$ \\
\hline \multicolumn{7}{|l|}{$\operatorname{Age}^{\mathrm{b}}$} \\
\hline $35-44$ & Ref & $0.80[0.63-1.01]$ & $0.81[0.63-1.05]$ & Ref & $0.54[0.45-0.64]$ & $0.54[0.45-0.64]$ \\
\hline $45-54$ & Ref & $0.90[0.72-1.13]$ & $1.02[0.80-1.32]$ & Ref & $0.74[0.62-0.87]$ & $0.79[0.66-0.95]$ \\
\hline $55-64$ & Ref & $0.97[0.78-1.21]$ & $1.15[0.91-1.45]$ & Ref & $0.98[0.83-1.14]$ & $1.06[0.90-1.24]$ \\
\hline $65-69^{*}$ & Ref & Ref & Ref & Ref & Ref & Ref \\
\hline \multicolumn{7}{|l|}{ Education } \\
\hline High school ${ }^{c}$ & Ref & $1.05[0.86-1.29]$ & $0.98[0.79-1.22]$ & Ref & $0.94[0.81-1.09]$ & $0.86[0.74-0.99]$ \\
\hline Some post-secondary ${ }^{d}$ & Ref & $0.89[0.73-1.08]$ & $0.87[0.71-1.07]$ & Ref & $0.94[0.81-1.09]$ & $0.80[0.69-0.93]$ \\
\hline Post secondary completed ${ }^{e}$ & Ref & $0.71[0.60-0.84]$ & $0.52[0.43-0.63]$ & Ref & $0.79[0.69-0.91]$ & $0.59[0.51-0.68]$ \\
\hline$<$ High school*f & Ref & Ref & Ref & Ref & Ref & Ref \\
\hline \multicolumn{7}{|l|}{ Marital status } \\
\hline Single (never married) ${ }^{\mathrm{g}}$ & Ref & $0.61[0.51-0.73]$ & $0.80[0.66-0.98]$ & Ref & $0.96[0.81-1.13]$ & $1.51[1.28-1.78]$ \\
\hline Divorced/separated/widowed ${ }^{\text {h }}$ & Ref & $0.91[0.78-1.05]$ & $0.91[0.77-1.08]$ & Ref & $0.86[0.78-0.96]$ & 0.89 [0.80-0.99] \\
\hline Married/Living with partner*i & Ref & Ref & Ref & Ref & Ref & Ref \\
\hline \multicolumn{7}{|l|}{ Household Income (\$CAN) } \\
\hline$<\$ 30,000$ & Ref & $0.64[0.53-0.78]$ & $0.63[0.51-0.78]$ & Ref & $1.25[1.10-1.42]$ & $2.15[1.88-2.46]$ \\
\hline$\$ 30,000-\$ 49,000$ & Ref & $0.71[0.63-0.81]$ & $0.73[0.63-0.84]$ & Ref & $1.34[1.22-1.48]$ & 1.74 [1.56-1.93] \\
\hline$\$ 50,000-\$ 79,000$ & Ref & $0.81[0.73-0.92]$ & $0.81[0.71-0.92]$ & Ref & $1.18[1.08-1.30]$ & $1.54[1.38-1.71]$ \\
\hline$\geq \$ 80,000^{*}$ & Ref & Ref & Ref & Ref & Ref & Ref \\
\hline \multicolumn{7}{|l|}{ Occupational status } \\
\hline Part Time & Ref & $0.97[0.79-1.18]$ & $0.78[0.62-0.98]$ & Ref & $0.85[0.78-0.93]$ & $0.73[0.66-0.80]$ \\
\hline Retired & Ref & 1.14 [0.94-1.39] & $1.36[1.10-1.68]$ & Ref & $0.96[0.83-1.10]$ & $0.85[0.73-0.99]$ \\
\hline Other ${ }^{k}$ & Ref & $0.94[0.76-1.16]$ & $1.41[1.13-1.76]$ & Ref & $0.93[0.84-1.02]$ & $0.96[0.86-1.06]$ \\
\hline Full Time* & Ref & Ref & Ref & Ref & Ref & Ref \\
\hline \multicolumn{7}{|l|}{ Geographic Location' } \\
\hline Rural & Ref & $1.19[1.06-1.34]$ & $1.34[1.18-1.52]$ & Ref & $1.16[1.06-1.26]$ & 1.37 [1.25-1.49] \\
\hline Urban* & Ref & Ref & Ref & Ref & Ref & Ref \\
\hline \multicolumn{7}{|l|}{ Smoking Status } \\
\hline Current daily smoker & Ref & $0.76[0.66-0.86]$ & $0.63[0.54-0.73]$ & Ref & $0.98[0.88-1.09]$ & $0.79[0.71-0.89]$ \\
\hline Current occasional smoker & Ref & $1.24[0.96-1.62]$ & $1.32[0.99-1.76]$ & Ref & $1.25[1.02-1.52]$ & $0.95[0.75-1.21]$ \\
\hline Former smoker & Ref & $1.45[1.30-1.61]$ & $1.71[1.51-1.93]$ & Ref & $1.22[1.13-1.32]$ & $1.41[1.30-1.53]$ \\
\hline Never smoker* & Ref & Ref & Ref & Ref & Ref & Ref \\
\hline
\end{tabular}

\#- Multinomial logistic regression is modelling the probablity of overweight and obesity

$¥$ - Considered the reference category in the multinomial logistic regression

*- Considered reference category for the sociodemographic variable

a- Alberta's Tomorrow Project baseline data, respondents to height and weight measurements

b- Continuous variable in years placed into categories

c- Completed high school

d-Completed some technical school/college training, or completed technical school/college training, or completed some part of university degree

e- Completed university degree, or completed some part of post-graduate university degree, or completed university post-graduate degree

f- Did not completed grade 8 , or completed grade 8 but not high school

g- Single and never have been married

h- Divorced, or separated, or widowed

i- Married, or not married but living with a partner

j- Income data are in response to a question about total household income before tax

k- "Other" includes homemaker, unemployed, student and other category

- Geographic Location was determined using postal codes, where the " 0 " as the middle numerical number indicates rural residence

† - Missing in body mass index or in at least one sociodemographic factor and hence excluded from the analysis $(n=259)$

₹- Missing in body mass index or in at least one sociodemographic factor and hence excluded from the analysis $(n=697)$ 
Table 3 Cross-sectional associations between body mass index ${ }^{a}$ category and history of chronic diseases in Alberta's Tomorrow Project Cohort

\begin{tabular}{|c|c|c|c|c|c|c|c|c|}
\hline \multirow[t]{2}{*}{ Chronic Disease $^{b}$} & \multicolumn{4}{|c|}{ Men $(n=12,062)(\%)$} & \multicolumn{4}{|c|}{ Women $(n=18,853)(\%)$} \\
\hline & $\mathrm{n}$ & Underweight and Normal ${ }^{\mathrm{C}}$ & Overweight & Obese & $\mathrm{n}$ & Underweight and Normal $^{\mathrm{C}}$ & Overweight & Obese \\
\hline Hypertension & 2980 & 12.4 & 43.2 & 44.4 & 4083 & 19.3 & 32.7 & 48.0 \\
\hline Angina & 539 & 16.1 & 42.7 & 41.2 & 373 & 22.8 & 33.5 & 43.7 \\
\hline High Cholesterol & 3787 & 15.9 & 49.0 & 35.2 & 4562 & 27.3 & 37.4 & 35.2 \\
\hline Heart Attack & 353 & 19.8 & 40.2 & 39.9 & 153 & 26.2 & 32.0 & 41.8 \\
\hline Stroke & 109 & 21.1 & 47.7 & 31.2 & 156 & 22.4 & 41.0 & 36.5 \\
\hline Diabetes & 694 & 13.1 & 34.7 & 52.2 & 814 & 13.3 & 22.1 & 64.6 \\
\hline Polyps in colon & 624 & 19.1 & 46.0 & 34.9 & 891 & 30.8 & 35.6 & 33.7 \\
\hline Crohn's Disease & 62 & 35.5 & 48.4 & 16.1 & 139 & 45.3 & 33.8 & 20.9 \\
\hline
\end{tabular}

Note: all the variables tested were highly significantly different, assessed by Pearson chi-square test $(p<.0001)$

${ }^{a} \mathrm{BMI}$ is derived from participant self-reported height and weight

${ }^{b}$ Chronic disease defined as self-report of a physician diagnosis

'Underweight and normal BMI categories grouped together due to small cell sizes

smokers, the odds of having a waist-to-hip ratio above the cut-off was greater for former smokers in men (OR: 1.52. 95\%CI: 1.35-1.72) and women (OR: 1.25, 95\% CI: 1.17-1.34).

The prevalence of participants with a waist-to-hip ratio above the cut-off was higher among those with a history of hypertension, angina, high cholesterol, stroke, diabetes and Crohn's disease (Table 6).

\section{Discussion}

In the ATP cohort, $77 \%$ of men and $60 \%$ of women had a BMI that exceeded the normal range, suggesting that more than two thirds of the participants were overweight or obese. The CCHS reported that $65.4 \%$ of men and $48.1 \%$ of women were classified as having a BMI above the normal range (Additional file 1: Table S1). Similar to the results observed in the present study, earlier analyses conducted on the first 11,865 participants enrolled in ATP showed a higher proportion of obesity in Alberta Tomorrow Project participants than CCHS (Cycle 1.1) participants residing in Alberta [7]. Some of the difference in prevalence of obesity between the CCHS and ATP could be due to the time periods in which the data were collected. The CCHS data were collected in 2005 , but $40.8 \%$ of the ATP data were collected between 2006 and 2009, when rates of overweight and obesity were higher.

BMI has been widely criticized as a measure of body size in health research due to its methodological limitations, particularly in terms of failing to address body composition [11]. When examining waist circumference, we observed high rates of abdominal obesity. Over $40 \%$ of the cohort reported waist circumferences that are associated with a significantly elevated risk of metabolic complications [9], with a higher proportion observed among women. These sex differences highlight the limitations of
BMI, where more men are classified as overweight, potentially because of their higher muscle mass, as compared to using waist circumference categories. In contrast, $57 \%$ of participants in the cohort had a waist-to-hip ratio above the cut-off established by the WHO, with substantially higher prevalence observed among men compared to women, which is expected given the differences in male and female body composition.

Consistent with previous research, excess body weight, as measured by BMI, waist circumference and waist-tohip ratio, was more prevalent among ATP participants with lower household income and education [9]. Across the different measures, the proportion of the study population with excess body weight was slightly higher in rural populations. Similar trends have been observed in other Canadian population-based surveys [12, 13] as well in the United States [14]. Although the reasons for greater prevalence of obesity in participants living in rural areas are not clear and warrant further investigation, one U.S. study showed that those living in rural areas were less physically active than those living in urban areas, which could contribute to the higher obesity rates [15].

Participants in ATP cohort who had excess body weight were more likely to report a history of hypertension, angina, diabetes, polyps in the colon, high cholesterol and Crohn's disease. In addition, these participants were more likely to have had a heart attack or stroke. Although the biological mechanism linking overweight/ obesity and chronic disease depends on the specific outcome, in general it involves bioactive mediators being released from adipose tissues, which in turn can lead to insulin resistance, inflammation and changes in blood pressure, lipid concentrations and coagulation [16].

Several limitations to the data presented in this analysis should be discussed. These data should not be considered 
Table 4 Waist circumference and waist-to-hip ratio ${ }^{a}$ categories of Alberta Tomorrow Project participants ${ }^{b}$ by socio-demographic variables

\begin{tabular}{|c|c|c|c|c|c|c|c|c|c|}
\hline \multirow[t]{3}{*}{ Variable } & \multicolumn{6}{|c|}{ Waist circumference (\%) } & \multicolumn{3}{|c|}{ Waist-to-hip Ratio (\%) } \\
\hline & \multicolumn{3}{|c|}{ Elevated Risk ${ }^{c}$} & \multicolumn{3}{|c|}{ Extremely High Risk ${ }^{c}$} & \multirow[b]{2}{*}{$\mathrm{n}$} & \multirow[b]{2}{*}{$<0.90$ (Men), $<0.85$ (Women) } & \multirow[b]{2}{*}{$\geq 0.90$ (Men), $\geq 0.85$ (Women) } \\
\hline & $\mathrm{n}$ & No & Yes & n & No & Yes & & & \\
\hline \multicolumn{10}{|l|}{ Sex } \\
\hline Men & 12,042 & 32.6 & 67.4 & 12,042 & 59.3 & 40.7 & 11,919 & 14.6 & 85.4 \\
\hline Women & 18,787 & 33.0 & 67.0 & 18,787 & 55.8 & 44.3 & 18,730 & 61.1 & 38.9 \\
\hline \multicolumn{10}{|l|}{ Age } \\
\hline $35-44$ & 10,019 & 42.6 & 57.4 & 10,019 & 66.2 & 33.8 & 9962 & 52.1 & 47.9 \\
\hline $45-54$ & 10,871 & 32.3 & 67.7 & 10,871 & 57.4 & 42.6 & 10,805 & 42.4 & 57.6 \\
\hline $55-64$ & 7375 & 24.4 & 75.6 & 7375 & 48.4 & 51.6 & 7339 & 35.4 & 64.7 \\
\hline$\geq 65$ & 2564 & 21.3 & 78.7 & 2564 & 45.7 & 54.3 & 2543 & 31.9 & 68.1 \\
\hline \multicolumn{10}{|l|}{ Education } \\
\hline High school not completed & 2981 & 23.2 & 76.8 & 2981 & 45.6 & 54.4 & 2946 & 30.1 & 69.9 \\
\hline High school completed & 5685 & 28.9 & 71.1 & 5685 & 52.7 & 47.3 & 5655 & 43.0 & 57.0 \\
\hline Some post-secondary ${ }^{d}$ & 6432 & 30.4 & 69.6 & 6432 & 53.4 & 46.6 & 6391 & 42.7 & 57.3 \\
\hline Post-secondary completed & 15,725 & 37.1 & 62.9 & 15,725 & 62.5 & 37.6 & 15,652 & 45.5 & 54.5 \\
\hline missing & 6 & & & 6 & & & 5 & & \\
\hline \multicolumn{10}{|l|}{ Marital Status } \\
\hline Married/Living with partner & 24,159 & 32.8 & 67.2 & 24,159 & 57.9 & 42.1 & 24,015 & 42.7 & 57.3 \\
\hline Single (never married) & 1815 & 35.8 & 64.2 & 1815 & 55.4 & 44.6 & 1803 & 40.1 & 59.9 \\
\hline Divorced/separated/widowed & 4847 & 31.8 & 68.2 & 4847 & 53.8 & 46.2 & 4823 & 45.7 & 54.3 \\
\hline missing & 8 & & & 8 & & & 8 & & \\
\hline \multicolumn{10}{|l|}{ Household Income $e^{e}$} \\
\hline$<\$ 30,000$ & 4050 & 27.0 & 73.0 & 4050 & 48.1 & 51.9 & 4013 & 39.8 & 60.2 \\
\hline$\$ 30,000-\$ 49,000$ & 8309 & 30.1 & 69.9 & 8309 & 53.5 & 46.5 & 8259 & 42.0 & 58.0 \\
\hline$\$ 50,000-\$ 79,000$ & 7777 & 32.9 & 67.1 & 7777 & 58.0 & 42.0 & 7727 & 41.7 & 58.3 \\
\hline$\geq \$ 80,000$ & 9955 & 37.8 & 62.2 & 9955 & 63.2 & 36.8 & 9918 & 45.7 & 54.3 \\
\hline missing & 738 & & & 738 & & & 732 & & \\
\hline \multicolumn{10}{|l|}{ Occupational Status } \\
\hline Full Time & 17,586 & 34.4 & 65.6 & 17,586 & 59.3 & 40.7 & 17,473 & 38.5 & 61.5 \\
\hline Part Time/Homemaker & 7523 & 35.9 & 64.1 & 7523 & 59.7 & 40.3 & 7495 & 58.5 & 41.5 \\
\hline Unemployed/Student & 795 & 34.5 & 65.5 & 795 & 55.5 & 44.5 & 790 & 46.1 & 53.9 \\
\hline Retired & 3870 & 21.9 & 78.1 & 3870 & 46.1 & 53.9 & 3845 & 35.2 & 64.8 \\
\hline Other & 1043 & 23.7 & 76.3 & 1043 & 44.7 & 55.3 & 1034 & 34.1 & 65.9 \\
\hline missing & 12 & & & 12 & & & 12 & & \\
\hline \multicolumn{10}{|l|}{ Geographic Location $^{f}$} \\
\hline Rural & 7286 & 28.6 & 71.4 & 7286 & 52.6 & 47.5 & 7236 & 40.5 & 59.6 \\
\hline Urban & 23,543 & 34.2 & 65.8 & 23,543 & 58.6 & 41.5 & 23,413 & 43.8 & 56.2 \\
\hline \multicolumn{10}{|l|}{ Smoking Status } \\
\hline Current daily smoker & 4753 & 36.6 & 63.4 & 4753 & 58.5 & 41.5 & 4719 & 38.6 & 61.4 \\
\hline Current occasional smoker & 963 & 27.1 & 72.9 & 963 & 59.2 & 40.8 & 953 & 42.5 & 57.5 \\
\hline Former smoker & 11,470 & 33.4 & 66.6 & 11,470 & 51.5 & 48.5 & 11,399 & 38.7 & 61.4 \\
\hline Never smoker & 13,612 & 35.9 & 64.2 & 13,612 & 61.3 & 38.7 & 13,547 & 48.2 & 51.8 \\
\hline missing & 31 & & & 31 & & & 31 & & \\
\hline
\end{tabular}


Table 5 Odds of higher waist circumference and waist-to-hip ratio by baseline sociodemographic characteristics in Alberta's Tomorrow Project Cohort from binary logistic regression ${ }^{\#}$

\begin{tabular}{|c|c|c|c|c|c|c|c|c|c|}
\hline \multirow[t]{3}{*}{ Sociodemographic Factors } & \multicolumn{5}{|c|}{ Waist circumference $(n=11,807) \dagger$} & & \multirow{2}{*}{\multicolumn{3}{|c|}{ Waist-Hip Ratio $(n=11,857) \neq$}} \\
\hline & \multicolumn{3}{|l|}{ Elevated Risk } & \multicolumn{3}{|c|}{ Extremely High Risk } & & & \\
\hline & $\begin{array}{l}\leq 94 \mathrm{~cm}(\mathrm{M}), \\
\leq 80 \mathrm{~cm}(\mathrm{~W})^{*}\end{array}$ & $>94 \mathrm{~cm}$ (men) & $>80$ (women) & $\begin{array}{l}\leq 102 \mathrm{~cm}(\mathrm{M}), \\
\leq 88(\mathrm{~W})^{*}\end{array}$ & $>102 \mathrm{~cm}$ (men) & $>88$ (women) & $\begin{array}{l}<0.90(\mathrm{M}) \\
<0.85(\mathrm{~W})^{*}\end{array}$ & $\geq 0.90$ (men) & $\geq 0.85$ (women) \\
\hline & OR $[95 \% \mathrm{Cl}]$ & & & & & & & & \\
\hline \multicolumn{10}{|l|}{$\mathrm{Age}^{\mathrm{b}}$} \\
\hline $35-44$ & Ref & $\begin{array}{l}0.54 \\
{[0.44-0.66]}\end{array}$ & $\begin{array}{l}0.44 \\
{[0.38-0.53]}\end{array}$ & Ref & $\begin{array}{l}0.60 \\
{[0.50-0.72]}\end{array}$ & $\begin{array}{l}0.54 \\
{[0.46-0.62]}\end{array}$ & Ref & $\begin{array}{l}0.39 \\
{[0.29-0.51]}\end{array}$ & $\begin{array}{l}0.45 \\
{[0.39-0.52]}\end{array}$ \\
\hline $45-54$ & Ref & $\begin{array}{l}0.80 \\
{[0.65-0.98]}\end{array}$ & $\begin{array}{l}0.67 \\
{[0.57-0.79]}\end{array}$ & Ref & $\begin{array}{l}0.84 \\
{[0.70-0.99]}\end{array}$ & $\begin{array}{l}0.76 \\
{[0.66-0.88]}\end{array}$ & Ref & $\begin{array}{l}0.64 \\
{[0.48-0.85]}\end{array}$ & $\begin{array}{l}0.68 \\
{[0.59-0.78]}\end{array}$ \\
\hline $55-64$ & Ref & $\begin{array}{l}0.96 \\
{[0.79-1.16]}\end{array}$ & $\begin{array}{l}0.96 \\
{[0.82-1.13]}\end{array}$ & Ref & $\begin{array}{l}1.05 \\
{[0.90-1.24]}\end{array}$ & $\begin{array}{l}1.03 \\
{[0.90-1.17]}\end{array}$ & Ref & $\begin{array}{l}0.98 \\
{[0.75-1.29]}\end{array}$ & $\begin{array}{l}0.89 \\
{[0.79-1.02]}\end{array}$ \\
\hline $65-69^{*}$ & Ref & Ref & Ref & Ref & Ref & Ref & Ref & Ref & Ref \\
\hline \multicolumn{10}{|l|}{ Education } \\
\hline High school ${ }^{c}$ & Ref & $\begin{array}{l}0.93 \\
{[0.78-1.10]}\end{array}$ & $\begin{array}{l}0.88 \\
{[0.76-1.01]}\end{array}$ & Ref & $\begin{array}{l}0.89 \\
{[0.77-1.03]}\end{array}$ & $\begin{array}{l}0.86 \\
{[0.76-0.98]}\end{array}$ & Ref & $\begin{array}{l}0.88 \\
{[0.70-1.12]}\end{array}$ & $\begin{array}{l}0.87 \\
{[0.77-0.99]}\end{array}$ \\
\hline Some post-secondary ${ }^{d}$ & Ref & $\begin{array}{l}0.87 \\
{[0.74-1.02]}\end{array}$ & $\begin{array}{l}0.84 \\
{[0.73-0.97]}\end{array}$ & Ref & $\begin{array}{l}0.91 \\
{[0.79-1.05]}\end{array}$ & $\begin{array}{l}0.85 \\
{[0.75-0.97]}\end{array}$ & Ref & $\begin{array}{l}0.85 \\
{[0.68-1.07]}\end{array}$ & $\begin{array}{l}0.85 \\
{[0.75-0.96]}\end{array}$ \\
\hline Post secondary completed ${ }^{e}$ & Ref & $\begin{array}{l}0.63 \\
{[0.54-0.73]}\end{array}$ & $\begin{array}{l}0.73 \\
{[0.64-0.84]}\end{array}$ & Ref & $\begin{array}{l}0.65 \\
{[0.57-0.74]}\end{array}$ & $\begin{array}{l}0.67 \\
{[0.60-0.75]}\end{array}$ & Ref & $\begin{array}{l}0.63 \\
{[0.51-0.77]}\end{array}$ & $\begin{array}{l}0.71 \\
{[0.64-0.80]}\end{array}$ \\
\hline$<$ High school*f & Ref & Ref & Ref & Ref & Ref & Ref & Ref & Ref & Ref \\
\hline \multicolumn{10}{|l|}{ Marital status } \\
\hline Single (never married) ${ }^{9}$ & Ref & $\begin{array}{l}0.74 \\
{[0.63-0.86]}\end{array}$ & $\begin{array}{l}1.09 \\
{[0.94-1.27]}\end{array}$ & Ref & $\begin{array}{l}0.89 \\
{[0.76-1.05]}\end{array}$ & $\begin{array}{l}1.38 \\
{[1.20-1.58]}\end{array}$ & Ref & $\begin{array}{l}1.00 \\
{[0.82-1.23]}\end{array}$ & $\begin{array}{l}1.19 \\
{[1.03-1.37]}\end{array}$ \\
\hline Divorced/separated/widowed ${ }^{\text {h }}$ & Ref & $\begin{array}{l}0.85 \\
{[0.74-0.96]}\end{array}$ & $\begin{array}{l}0.83 \\
{[0.76-0.91]}\end{array}$ & Ref & $\begin{array}{l}0.94 \\
{[0.83-1.07]}\end{array}$ & $\begin{array}{l}0.93 \\
{[0.85-1.02]}\end{array}$ & Ref & $\begin{array}{l}0.93 \\
{[0.78-1.10]}\end{array}$ & $\begin{array}{l}0.91 \\
{[0.83-0.99]}\end{array}$ \\
\hline Married/Living with partner ${ }^{* i}$ & Ref & Ref & Ref & Ref & Ref & Ref & Ref & Ref & Ref \\
\hline \multicolumn{10}{|l|}{ Household Income (\$CAN) $)^{j}$} \\
\hline$<\$ 30,000$ & Ref & $\begin{array}{l}0.82 \\
{[0.70-0.97]}\end{array}$ & $\begin{array}{l}1.78 \\
{[1.58-2.00]}\end{array}$ & Ref & $\begin{array}{l}0.92 \\
{[0.79-1.08]}\end{array}$ & $\begin{array}{l}1.78 \\
{[1.60-1.99]}\end{array}$ & Ref & $\begin{array}{l}0.82 \\
{[0.66-1.01]}\end{array}$ & $\begin{array}{l}1.68 \\
{[1.51-1.88]}\end{array}$ \\
\hline$\$ 30,000-\$ 49,000$ & Ref & $\begin{array}{l}0.92 \\
{[0.82-1.02]}\end{array}$ & $\begin{array}{l}1.53 \\
{[1.40-1.67]}\end{array}$ & Ref & $\begin{array}{l}0.91 \\
{[0.82-1.02]}\end{array}$ & $\begin{array}{l}1.56 \\
{[1.43-1.69]}\end{array}$ & Ref & $\begin{array}{l}1.06 \\
{[0.92-1.22]}\end{array}$ & $\begin{array}{l}1.35 \\
{[1.23-1.47]}\end{array}$ \\
\hline$\$ 50,000-\$ 79,000$ & Ref & $\begin{array}{l}0.96 \\
{[0.87-1.06]}\end{array}$ & $\begin{array}{l}1.36 \\
{[1.25-1.48]}\end{array}$ & Ref & $\begin{array}{l}0.93 \\
{[0.85-1.03]}\end{array}$ & $\begin{array}{l}1.37 \\
{[1.26-1.49]}\end{array}$ & Ref & $\begin{array}{l}1.07 \\
{[0.94-1.22]}\end{array}$ & $\begin{array}{l}1.25 \\
{[1.15-1.37]}\end{array}$ \\
\hline$\geq \$ 80,000^{*}$ & Ref & Ref & Ref & Ref & Ref & Ref & Ref & Ref & Ref \\
\hline \multicolumn{10}{|l|}{ Occupational status } \\
\hline Part Time & Ref & $\begin{array}{l}0.99 \\
{[0.83-1.17]}\end{array}$ & $\begin{array}{l}0.80 \\
{[0.74-0.87]}\end{array}$ & Ref & $\begin{array}{l}0.89 \\
{[0.76-1.05]}\end{array}$ & $\begin{array}{l}0.82 \\
{[0.75-0.89]}\end{array}$ & Ref & $\begin{array}{l}1.12 \\
{[0.88-1.44]}\end{array}$ & $\begin{array}{l}0.89 \\
{[0.82-0.96]}\end{array}$ \\
\hline Retired & Ref & $\begin{array}{l}1.29 \\
{[1.08-1.53]}\end{array}$ & $\begin{array}{l}1.00 \\
{[0.87-1.15]}\end{array}$ & Ref & $\begin{array}{l}1.27 \\
{[1.09-1.47]}\end{array}$ & $\begin{array}{l}0.96 \\
{[0.85-1.08]}\end{array}$ & Ref & $\begin{array}{l}0.95 \\
{[0.75-1.20]}\end{array}$ & $\begin{array}{l}0.98 \\
{[0.87-1.11]}\end{array}$ \\
\hline Other $^{k}$ & Ref & $\begin{array}{l}1.38 \\
{[1.15-1.66]}\end{array}$ & $\begin{array}{l}0.95 \\
{[0.87-1.04]}\end{array}$ & Ref & $\begin{array}{l}1.39 \\
{[1.17-1.64]}\end{array}$ & $\begin{array}{l}1.00 \\
{[0.92-1.09]}\end{array}$ & Ref & $\begin{array}{l}1.10 \\
{[0.87-1.38]}\end{array}$ & $\begin{array}{l}1.03 \\
{[0.95-1.13]}\end{array}$ \\
\hline Full Time* & Ref & Ref & Ref & Ref & Ref & Ref & Ref & Ref & Ref \\
\hline \multicolumn{10}{|l|}{ Geographic Location' } \\
\hline Rural & Ref & $\begin{array}{l}1.19 \\
{[1.08-1.32]}\end{array}$ & $\begin{array}{l}1.19 \\
{[1.10-1.29]}\end{array}$ & Ref & $\begin{array}{l}1.16 \\
{[1.06-1.27]}\end{array}$ & $\begin{array}{l}1.17 \\
{[1.09-1.25]}\end{array}$ & Ref & $\begin{array}{l}1.24 \\
{[1.09-1.41]}\end{array}$ & $\begin{array}{l}1.05 \\
{[0.97-1.12]}\end{array}$ \\
\hline Urban* & Ref & Ref & Ref & Ref & Ref & Ref & Ref & Ref & Ref \\
\hline \multicolumn{10}{|l|}{ Smoking Status } \\
\hline Current daily smoker & Ref & $\begin{array}{l}0.81 \\
{[0.72-0.91]}\end{array}$ & $\begin{array}{l}1.01 \\
{[0.91-1.11]}\end{array}$ & Ref & $\begin{array}{l}0.93 \\
{[0.83-1.05]}\end{array}$ & $\begin{array}{l}1.03 \\
{[0.94-1.13]}\end{array}$ & Ref & $\begin{array}{l}1.14 \\
{[0.98-1.33]}\end{array}$ & $\begin{array}{l}1.38 \\
{[1.26-1.51]}\end{array}$ \\
\hline Current occasional smoker & Ref & $\begin{array}{l}1.15 \\
{[0.92-1.42]}\end{array}$ & $\begin{array}{l}1.25 \\
{[1.03-1.51]}\end{array}$ & Ref & $\begin{array}{l}1.31 \\
{[1.06-1.61]}\end{array}$ & $\begin{array}{l}1.03 \\
{[0.86-1.24]}\end{array}$ & Ref & $\begin{array}{l}0.97 \\
{[0.75-1.26]}\end{array}$ & $\begin{array}{l}1.27 \\
{[1.06-1.53]}\end{array}$ \\
\hline Former smoker & Ref & $\begin{array}{l}1.48 \\
{[1.35-1.62]}\end{array}$ & $\begin{array}{l}1.35 \\
{[1.26-1.45]}\end{array}$ & Ref & $\begin{array}{l}1.49 \\
{[1.36-1.62]}\end{array}$ & $\begin{array}{l}1.29 \\
{[1.21-1.38]}\end{array}$ & Ref & $\begin{array}{l}1.52 \\
{[1.35-1.72]}\end{array}$ & $\begin{array}{l}1.25 \\
{[1.17-1.34]}\end{array}$ \\
\hline Never smoker* & Ref & Ref & Ref & Ref & Ref & Ref & Ref & Ref & Ref \\
\hline
\end{tabular}


\#- Binary logistic regression is modelling the probability of higher waist circumference and waist-to-hip ratio categories

$¥$ - Considered the reference category in a binary logistic regression

*- Considered reference category for the sociodemographic variable

a- Alberta's Tomorrow Project baseline data, respondents to waist and hip circumference

b- Continuous variable in years placed into categories

c- Completed high school

d- Completed some technical school/college training, or completed technical school/college training, or completed some part of university degree

e- Completed university degree, or completed some part of post-graduate university degree, or completed university post-graduate degree

$\mathrm{f}$ - Did not completed grade 8 , or completed grade 8 but not high school

g- Single and never have been married

h- Divorced, or separated, or widowed

i- Married, or not married but living with a partner

j- Income data are in response to a question about total household income before tax etc.

k- "Other" includes homemaker, unemployed, student and other category

I- Geographic Location was determined using postal codes, where the " 0 " as the middle numerical number indicates rural residence

$\dagger-$ Missing in waist circumference or in at least one sociodemographic factor and hence excluded from the analysis ( $n=309)$

\#- Missing in waist-to-hip ratio or in at least one sociodemographic factor and hence excluded from the analysis $(n=259)$

representative of the Alberta population as a whole. In addition, misclassification by respondent bias is a potential limitation that should be considered. It has been previously reported that weight-related values are underreported, while height is exaggerated [17]. The cohort does not include young adults (age 18-<35), who have been shown to have a slightly lower prevalence of obesity than the general Alberta population [13]. We observed several significant associations in this analysis which may be in part due to the large sample sizes being examined.

Although we did not evaluate prospective trends in this analysis, national data suggest that abdominal obesity is especially on the rise $[18,19]$. Overweight/obesity in Canada is widely known to be associated with various adverse health outcomes [20]. Furthermore, complications of obesity expand beyond physical health into possible psychological concerns [21] that can have an equally negative effect on the population and the healthcare system. Implementation of existing, and development of novel, interventions targeted at reducing obesity in Alberta should be a public health priority. Including measures of excess body weight in follow-up questionnaires will be important for understanding how measures of BMI, waist circumference and waist-to-hip ratio change over time and what impact these changes have on disease outcomes.

There are a wide range of factors that could be affecting the overweight/obesity trends in the Alberta cohort. It has been demonstrated repeatedly that socioeconomic factors have an overarching impact. For instance, it has been reported that $34 \%$ of BMI status can be attributed to educational background, marital status, smoking status and to a less significant extent, sleep deprivation based on results from a cohort study [22]. In the current study, education $(p<0.001)$, marital status $(p<0.001)$ and smoking status $(p<0.001)$ were significantly associated with BMI in both men and women. These relationships between socioeconomic status and BMI are possibly attributable to the differential distribution of certain lifestyle behaviours across socioeconomic categories [23].

Table 6 Cross-sectional associations between waist circumference, hip-to-waist ratio ${ }^{a}$ and history of chronic diseases in Alberta's Tomorrow Project Cohort

\begin{tabular}{|c|c|c|c|c|c|c|c|c|c|}
\hline \multirow{3}{*}{$\begin{array}{l}\text { Chronic } \\
\text { Disease }^{b}\end{array}$} & \multicolumn{6}{|c|}{ Waist Circumference (\%) } & \multirow{2}{*}{\multicolumn{3}{|c|}{ Waist-to-Hip Ratio }} \\
\hline & \multicolumn{3}{|c|}{ Elevated Risk ${ }^{c}$} & \multicolumn{3}{|c|}{ Extremely High Risk ${ }^{c}$} & & & \\
\hline & $\mathrm{n}$ & No & Yes & $n$ & No & Yes & $\mathrm{n}$ & $<0.90$ (Men), < 0.85 (Women) & $\geq 0.90$ (Men), $\geq 0.85$ (Women) \\
\hline Hypertension & 7029 & 14.7 & 85.3 & 7029 & 35.0 & 65.0 & 6980 & 26.7 & 73.3 \\
\hline Angina & 907 & 18.2 & 81.8 & 907 & 38.3 & 61.7 & 895 & 22.5 & 77.5 \\
\hline High Cholesterol & 8323 & 21.3 & 78.7 & 8323 & 45.2 & 54.8 & 8265 & 29.7 & 70.3 \\
\hline Heart Attack & 504 & 19.3 & 80.8 & 504 & 39.5 & 60.5 & 500 & 15.2 & 84.8 \\
\hline Stroke & 264 & 18.9 & 81.1 & 264 & 36.7 & 63.3 & 261 & 27.6 & 72.4 \\
\hline Diabetes & 1495 & 11.9 & 88.1 & 1495 & 24.5 & 75.5 & 1478 & 16.0 & 84.0 \\
\hline Polyps in colon & 1507 & 21.5 & 78.5 & 1507 & 45.0 & 55.0 & 1501 & 33.0 & 67.0 \\
\hline Crohn's Disease & 202 & 30.7 & 69.3 & 202 & 61.9 & 38.1 & 202 & 42.1 & 57.9 \\
\hline
\end{tabular}

Note: all the variables tested were highly significantly different, assessed by Pearson chi-square test $(p<0.001)$

${ }^{a}$ Waist circumference and waist-to-hip ratio derived from participant self-reported measurements. Waist circumference measurements are missing for 243 participants, waist-to-hip ratio missing for 423 participants

${ }^{\mathrm{b}} \mathrm{Chronic}$ disease defined as self-report of a physician diagnosis

'Elevated risk for waist circumference defined as $>94 \mathrm{~cm}$ for men and $>80 \mathrm{~cm}$ for women. Extremely high risk defined as $>102 \mathrm{~cm}$ for men and $>88 \mathrm{~cm}$ for women 


\section{Conclusion}

These analyses suggest that excess body weight, as measured by BMI, waist circumference and waist-to-hip ratio is highly prevalent in the cohort. The prevalence of overweight/obesity was higher in the lower education and income groups. Our data further implies that there are multiple chronic conditions associated with excess body weight. Multi-faceted approaches targeting the governmental, community and individual-level changes will be required to improve the energy balance of Albertans and improve subsequent health outcomes.

\section{Additional file}

Additional file 1: Table S1. Age and BMl distributions at enrolment in Alberta's Tomorrow Project compared with the Canadian Community Health Survey (Cycle 3.1). Table S1 compares the age and BMI distributions of Alberta's Tomorrow project participants at enrolment and Canadian Community Health Survey respondents (cycle 3.1) from Alberta. (DOCX 17 kb)

\section{Abbreviations}

ATP: Alberta's Tomorrow project; BMI: Body mass index; CCHS: Canadian Community Health Survey; HLQ: Health and Lifestyle Questionnaire; SD: Standard deviation; VIF: Variance inflation factor

\begin{abstract}
Acknowledgements
Alberta's Tomorrow Project is only possible due to the commitment of its research participants, its staff and its funders. The views expressed herein represent the views of the author(s) and not of Alberta's Tomorrow Project or any of its funders. The data product presented here from CCHS is provided 'as-is,' and Statistics Canada makes no warranty, either express or implied, including but not limited to, warranties of merchantability and fitness for a particular purpose. In no event will Statistics Canada be liable for any direct, special, indirect, consequential or other damages, however caused.
\end{abstract}

\section{Funding}

Alberta's Tomorrow Project funders: Alberta Cancer Foundation, Canadian Partnership Against Cancer, Alberta Cancer Prevention Legacy Fund (administered by Alberta Innovates - Health Solutions) and substantial in kind funding from Alberta Health Services. Christine Friedenreich holds a Health Senior Scholar Award from Alberta Innovates-Health Solutions and the Alberta Cancer Foundation's Weekend to End Women's Cancers Breast Cancer Chair. Darren Brenner holds a Canadian Cancer Society Career Development Award in Cancer Prevention.

\section{Availability of data and materials}

Questionnaire data will be available to external researchers upon successful completion and approval of an access request. Access requests from national and international researchers are welcome. Information and details on how to request access to Alberta's Tomorrow Project data can be found at www.myATP.ca, or by emailing ATP.Research@ahs.ca. The analysis in Additional file 1: Table S1 is based on the Statistics Canada Canadian Community Health Survey, Cycle 3.1, Public Use Microdata File (catalogue no. $82 \mathrm{M} 0013 \mathrm{XCD}$ ) (2005). All computations, use and interpretation of these data are entirely those of the authors of this paper.

\section{Authors' contributions}

DRB, PJR and CMF were responsible for the study conception. CMF, DRB, PJR, AEP, TRH and AA contributed substantially to the study design and interpretation of the data. AA completed the analyses. DRB and AEP were major contributors in writing the manuscript. All authors read and gave final approval of this version to be published and agreed to be guarantors of the work.

\section{Ethics approval and consent to participate}

Ethical approval for recruitment and data collection was obtained from the former Alberta Cancer Board Research Ethics Committee and the University of Calgary Conjoint Health Research Ethics Board. Ethical approval for the current study was obtained from the Health Research Ethics Board of Alberta - Cancer Committee (ref \# 25523). Participants were enrolled if they returned a completed Health and Lifestyle Questionnaire and signed consent form. Participants were also asked to provide their Personal Health Number for data linkage with the Alberta Cancer Registry and the provincial health ministry to facilitate future research on health services utilization and outcomes, including cancer diagnoses.

\section{Consent for publication}

Not applicable.

\section{Competing interests}

The authors declare that they have no competing interests.

\section{Publisher's Note}

Springer Nature remains neutral with regard to jurisdictional claims in published maps and institutional affiliations.

\section{Author details}

${ }^{1}$ Department of Cancer Epidemiology and Prevention Research, CancerControl Alberta, Alberta Health Services Holy Cross Centre, Room 514, Box ACB, 2210 2nd Street SW, Calgary, AB T2S 3C3, Canada. ²Department of Oncology and Department of Community Health Sciences, Cumming School of Medicine, University of Calgary, Calgary, Canada. ${ }^{3}$ Cancer Measurement, Outcomes, Research and Evaluation (C-MORE), CancerControl Alberta, Alberta Health Services, 10123-99 Street NW, Edmonton, AB T5J 3H1, Canada. ${ }^{4}$ Department of Agricultural, Food and Nutritional Science, Faculty of Agricultural, Life and Environmental Sciences, University of Alberta, Edmonton, Canada.

Received: 3 April 2017 Accepted: 6 November 2017 Published online: 25 November 2017

References

1. World Health Organization. Global health risks: mortality and burden of disease attributable to selected major risks. Geneva: World Health Organization; 2009.

2. Whitlock G, Lewington S, Sherliker P, Clarke R, Emberson J, Halsey J, Qizilbash N, Collins R, Peto R. Body-mass index and cause-specific mortality in 900000 adults: collaborative analyses of 57 prospective studies. Lancet. 2009;373(9669):1083-96.

3. Huang TT, Drewnowski A, Kumanyika SK, Glass TA. A systems-oriented multilevel framework for addressing obesity in the 21 st century. Prev Chronic Dis. 2009;6(3):A82.

4. Stevens GA, Singh GM, Lu Y, Danaei G, Lin JK, Finucane MM, Bahalim AN, McIntire RK, Gutierrez HR, Cowan M, et al. National, regional, and global trends in adult overweight and obesity prevalences. Popul Health Metr. 2012;10(1):22.

5. The Public Health Agency of Canada and the Canadian Institute for Health Information. Obesity in Canada. Toronto: The Public Health Agency of Canada and the Canadian Institute for Health Information; 2011.

6. Anis AH, Zhang W, Bansback N, Guh DP, Amarsi Z, Birmingham CL. Obesity and overweight in Canada: an updated cost-of-illness study. Obes Rev. 2010;11(1):31-40.

7. Bryant H, Robson PJ, Ullman R, Friedenreich C, Dawe U. Population-based cohort development in Alberta, Canada: a feasibility study. Chronic diseases in Canada. 2006;27(2):51-9.

8. Robson PJ, Solbak NM, Haig TR, Whelan HK, Vena JE, Akawung AK, Rosner WK, Brenner DR, Cook LS, Csizmadi I, Kopciuk KA, McGregor SE, Friedenreich CM. Design, methods and demographics from phase I of Alberta's Tomorrow Project cohort: a prospective cohort profile. CMAJ Open. 2016;4(3):E515-27.

9. World Health Organization. Waist circumference and waist-hip ratio: report of the WHO expert consultation; Geneva, 8-11 December 2008. Geneva: World Health Organization; 2011.

10. Statistics Canada: Table 105-0407 — Measured adult body mass index (BMI), by age group and sex, household population aged 18 and over excluding pregnant females. In: Canadian Community Health Survey CCHS 3.1), Canada, every 2 years. CANSIM. Ottawa: Statistics Canada; 2009. In. 
11. Nevill AM, Stewart AD, Olds T, Holder R. Relationship between adiposity and body size reveals limitations of BMI. Am J Phys Anthropol. 2006;129(1):151-6.

12. Mitura V, Bollman RD. The health or rural Canadians: a rural-urban comparison of health indicators. Rural and Small Town Canada Analysis Bulletin. Stat Can. 2003;4(6):1-23.

13. Li FX, Robson PJ, Ashbury FD, Hatcher J, Bryant HE. Smoking frequency, prevalence and trends, and their socio-demographic associations in Alberta, Canada. Can J Public Health. 2009;100(6):453-8.

14. Befort CA, Nazir N, Perri MG: Prevalence of obesity among adults from rural and urban areas of the United States: findings from NHANES (2005-2008). J Rural Health 2012, 28(4):392-397.

15. Patterson PD, Moore CG, Probst JC, Shinogle JA. Obesity and physical inactivity in rural America. J Rural Health. 2004;20(2):151-9.

16. Van Gaal LF, Mertens IL, De Block CE. Mechanisms linking obesity with cardiovascular disease. Nature. 2006:444(7121):875-80.

17. Connor Gorber S, Tremblay M, Moher D, Gorber B. A comparison of direct vs. self-report measures for assessing height, weight and body mass index: a systematic review. Obes Rev. 2007;8(4):307-26.

18. Sheehan TJ, DuBrava S, DeChello LM, Fang Z. Rates of weight change for black and white Americans over a twenty year period. Int J Obes Relat Metab Disord. 2003;27(4):498-504

19. Janssen I, Shields M, Craig CL, Tremblay MS. Prevalence and secular changes in abdominal obesity in Canadian adolescents and adults, 1981 to 2007-2009. Obes Rev. 2011;12(6):397-405.

20. Raine K. Overweight and obesity in Canada, a population health perspective in. CIHI: Ottawa; 2004.

21. Wang F, Wild TC, Kipp W, Kuhle S, Veugelers PJ. The influence of childhood obesity on the development of self-esteem. Health Rep. 2009;20(2):21-7.

22. Asil E, Surucuoglu MS, Cakiroglu FP, Ucar A, Ozcelik AO, Yilmaz MV, Akan LS. Factors that affect body mass index of adults. Pak J Nutr. 2014;13(5):255-60.

23. Grabner M. BMI trends, socioeconomic status, and the choice of dataset. Obesity Facts. 2012;5(1):112-26.

\section{Submit your next manuscript to BioMed Central and we will help you at every step:}

- We accept pre-submission inquiries

- Our selector tool helps you to find the most relevant journal

- We provide round the clock customer support

- Convenient online submission

- Thorough peer review

- Inclusion in PubMed and all major indexing services

- Maximum visibility for your research

Submit your manuscript at www.biomedcentral.com/submit 